JEL Classification: E00, E03, E3

\title{
ЗАВЕРШЕННЯ ФОРМУВАННЯ НАУКИ МАКРОЕКОНОМІКИ
}

\author{
Бабайлов В. К., канд. економ. наук, доцент \\ Приходько Д. О., канд. економ. наук, доцент \\ Харківський національний автомобільно-дорожній університет
}

Постановка проблеми. Як доведено в [1] у будь-якій науці зобов'язано бути чотири елементи змісту: об'єкт (межи науки); предмет (проблемна частина об’єкту); методика апробації (вирішення проблеми) предмету; парадигма. Відсутність хоча б одного $з$ таких елементів, незавершеність науки, означає відсутність усієї науки. До 2013-18 років, як це не дивно, були сформовані тільки два перших елементи окремих наук. Будь-яка наука, й наука макроекономіка зокрема, $\epsilon$ вищим рівнем знання, а тому й найбільш ефективним засобом рішення проблем практики макроекономіки. Її незавершеність, іï відсутність, суттєво знижує ефективність практики. Тому завершення формування науки макроекономіки є актуальним.

Аналіз останніх досліджень і публікацій. Він свідчить про те, що в останні роки стався значний прогрес в розвитку наук; було встановлено: кількість елементів змісту будь-якої науки - чотири; визначені ці чотири елементи (об'єкт; предмет; методика апробації предмету; результат цієї апробації); встановлений сенс кожного з чотирьох елементів та їх взаємозв'язок. Важливим результатом цих років $\epsilon$ встановлення критерію науковості. Однак й досі науковими визначають явища, які не задовольняють встановленому в [2] критерію науковості. Згідно з цим критерієм, до наукових необхідне відносити тільки такі явища, результатом яких $€$ тільки наука. На думку авторів встановлення критерія науковості був важливіший крок в напрямку встановлення порядку в визначенні рівнів знання. Другим важливим кроком у ці роки було завершення формування наук основних сфер діяльності людства: економіки, менеджменту, маркетингу, підприємництва, інженерії, методології та деяких інших. У них було остаточно зроблено визначення кожного з чотирьох елементів науки: об'єктом будь-якої науки є ії основна теорія; предметом - iї основний закон; методикою апробаиії основного закону - методика «Час»; парадигмою - результат апробації основного закону методикою «Час».

У свою чергу, був розкритий сенс кожного 3 цих трьох елементів змісту науки: Основна теорія (об'єкт науки) - це організація всіх приватних теорій, їх апробація, тобто, узагальнення приватних законів, і отримання результату цього узагальнення - основного закону; саме основний закон стає вже предметом науки. Основний закон (предмет науки, проблемна частина іï об'єкту) має відповідно одну, таку проблему - це відсутність апробації, перевірки характеру поведінки основного закону у часі, це відсутність апробації основного закону методикою «ЧАС»; власне ця методика й стає третім елементом змісту науки. 
Методика «ЧАС» - це скорочене для простоти використання відомої методики історичного-логічного Гегеля [1]. Ї̈̈ використання показує, як змінюються у часі конкретні форми основного закону науки. Апробація основного закону науки методикою «ЧАС» веде до визначення парадигми - четвертого остаточного елементу змісту науки, тобто - до завершення формування науки [1]. Парадигма - це четвертий і останній елемент змісту науки. Її сенс - глобальна, тобто, всесвітня стратегія поведінки всього людства у конкретній сфері його діяльності. У 2013-2018 роках вперше в світі були розроблені парадигми основних сфер діяльності людства: економіки, менеджменту, маркетингу, підприємництва, інженерії, методології і деяких інших. Це означало , що тільки у цей час було завершено формування цих важливіших наук.

Невирішені складові загальної проблеми. Однак досі не завершено формування значної кількості інших важливих наук. Й особливо невирішеними складовими цієї загальної проблеми $\epsilon$ незавершеність формування трьох важливих наук: мікро-, макро-, мегаекономіки.

Формулювання мети статі. Метою даного дослідження є завершення формування науки макроекономіки. Задач: визначити чотири елементи змісту науки макроекономіки (основну теорію, основний закон, методики апробації основного закону, парадигми); зробити узагальнення проведеного аналізу, тобто, сформулювати основні результати дослідження.

Методики дослідження: порівняння, системного та комплексного підходу, абстрактно-логічного аналізу, узагальнення та абстрагування, логічна генерація висновків.

Виклад основного матеріалу дослідження. При вирішенні задач автори виходили вже з відомих і доведених фактів, підтверджених усією практикою досліджень, що об’єктом науки макроекономіки (як й будь-якої науки) є ï основна теорія; предметом - ï основний закон; методикою апробації іï основного закону - методика «Час»; парадигмою - результат апробації основного закону методикою «Час».

При цьому було встановлено, що у формування першого елементу змісту макроекономіки - основної теорії, у формування іiї об'єкту (приватних теорій макроекономіки) значний внесок зробили: Аристотель (він обгрунтував хрематистику і капітал як типові економічні явища); Монкретьен (вперше ввів поняття політична, тобто, державна, національна економіка, макроекономіка); Маркс (вперше ввів закон обігу грошей як макроекономічний закон); Сміт (створив економічну теорію трудової вартості) [3]; Кєне (вперше зробив спробу макроаналізу за допомогою економічної таблиці) [4]; У. Петті (творець політичної, тобто, державної, макроекономічної арифметики) [5]; А. Маршалл (вперше зробив головний внесок у формування науки макроекономіки визначив основний закон макроекономіки) [6] тощо. Головним наслідком,

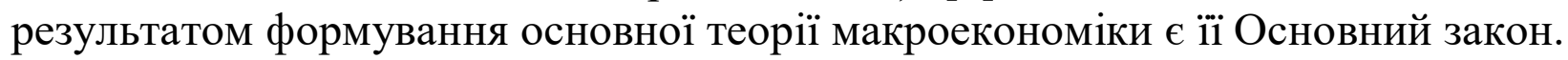

Основний закон макроекономіки - це сутність макроекономіки, це організація макроекономічної вартості у формі рівноважної иіни (РЦ), це створення рівноважної циіни. Рівноважна ціна - це ціна, яка встановлюється 
тільки при рівності сукупного попиту і сукупної пропозиції [3]. При порушенні основного закону макроекономіки рівноважна ціна зникає і залишається просто ціна, яка встановлюється на ринку; це особливий стан макроекономіки, це безлад, «хвороба» макроекономіки, - це інфляиія. При цьому, якщо СПп>СПр, то підприємствам вигідне підвищувати ціну і навпаки, якщо СПп< СПр, то вигідне зменшувати ціну.

У даній статі мова йде не про вибір поведінки суб'єктів ринку по відношенню до організації найбільш вигідної ціни у час інфляції, - тут мова йде про інше - тільки про рівноважний стан макроекономіки, про ії стан тільки при рівності СПп=СПр, тільки про її рівноважну ияіну, і тільки про фактори, які впливають не на будь-яку ціну, а саме тільки про фактори, які впливають тільки на рівноважну ціну. Й, як слідує з літературних джерел, такі фактори існують [7], тобто навіть рівноважна ціна може змінюватися, тобто змінюватися навіть при дотримані, непорушені основного закону макроекономіки. Цими факторами є лише два - це конкурениія $i$ монополія (тут під монополією для спрощення розуміється і олігополія, і олігопсонія, і монопсонія). А якщо ще точніше існує тільки один фактор як співвідношення конкуренції і монополії. Не зайвою буде така примітка - паралельно, незалежно може періодично виникати зміна ціни й від порушення основного закону вартості. Однак у даній публікації мова йде тільки про рівноважну ціну, тільки про зміну рівноважної ціни від співвідношення конкуренції і монополії.

Як відомо 3 [3] (а також з інших джерел [8-10]) це співвідношення було незмінним тільки у нутрі історичних епох: Доіндустріальній, Індустріальній і Постіндустріальній. Так, у Доіндустріальну епоху в основному конкуренція переважала монополії, це була конкуренція вільна від впливу монополій, це вільна конкуренція; ступінь співвідношення монополії і конкуренції залежав в основному лише від ступеню однієї конкуренції. Тобто, закон попиту i пропозиції контролювався в основному ступенем якості товару. Тому рівноважна ціна залежала в основному від якості товару, тобто від величини трудових витрат: чим більше були витрати праці, тим більше була рівноважна ціна. При цьому попит і пропозиція досягали відносно незначної величині.

Ситуація різко змінюється при переході до машинного виробництва в Індустріальну епоху; попит і пропозиція теж зростають до небувалих розмірів.

Змінюється й співвідношення конкуренції і монополії. Вільна конкуренція перетворюється у монопольну конкуренцію. Рівноважна ціна вже залежить не тільки від поведінки виробника у сфері виробництва і подальшої зміни ступеню вільної конкуренції, а й від поведінки на ринку. Й дійсно виробники на виробництві всі знаходяться в однакових умовах, однаково впливають на рівноважну ціну - лише за рахунок змін витрат праці. Але на ринку можливий ще й зговір частки як виробників, так і покупців: при зговорі (при монополізмі) вони підвищують рівноважну ціну не за рахунок додаткових витрат праці, а за рахунок перерозподілу вартості з не монополістами, а з вільними конкурентами; тому рівноважна ціна вже залежить від співвідношення конкуренції і монополії. При цьому в Індустріальну епоху й особливо на іiі початку, у період «дикого» 
капіталізму співвідношення конкуренції i монополії було виключне неконтрольованим, стихійним. Неконтрольованою, стихійною стає й рівноважна ціна. У подальшому держава за рахунок антимонопольного законодавства намагається впливати на співвідношення конкуренції і монополії. Однак, як показує практика, цих дій виявляється недостатньо. Дослідження видатних західних економістів Фрідріха фон Хайека, Вальтера Ойкена, Альфреда МюллерАрмака привели до висновку про необхідність задіяти й інші аспекти - аспекти соціального характеру, в тому числі, й впливу на співвідношення конкуренції $\mathrm{i}$ монополії [7]. Останнє є досі невирішеною до кінця проблемою.

Проте з точки зору мети даної публікації, - завершення формування науки макроекономіки, - проведений аналіз Доіндустріальній та Індустріальній епох, встановлення основного закону макроекономіки дозволяє сформулювати важливіший, остаточний, четвертий елемент змісту науки макроекономіки - іiі парадигми, як результат апробаиії основного закону методикою «Час».

Як доведено у [1], парадигма - це глобальна стратегія, тобто стратегія поведінки всього людства у конкретній сфері його діяльності: економіки, менеджменту, маркетингу, інженерії, адміністрації тощо. Парадигма макроекономіки - це глобальна стратегія поведінки всього людства у сфері макроекономіки.

При розробці парадигм макроекономіки автори виходили 3 доведеного раніше висновку, що основний закон макроекономіки (і відповідно рівноважна ціна) у самому загальному вигляді залежать від співвідношення головних факторів - конкуренції $i$ монополії. В даному контексті монополія, далі визначається переважно як будь-яке панування, диктат, як одного суб'єкту ринку, так й декількох. Так, у Доіндустріальну епоху конкуренція переважала над монополією; монополій було небагато, їх роль була незначна; тому конкуренція була в основному незалежною від монополії, це була вільна конкуренція. Тому Доіндустріальній епохі відповідав свій, особистий основний закон макроекономіки і особиста рівноважна ціна. Й цієї епохі відповідала й відповідна парадигма; це була глобальна стратегія вільної конкуренції, перша, минула парадигма макроекономіки.

В Індустріальну епоху масштаби і роль монополій посилюється. Основний закон також змінюється відповідно іншому співвідношенню конкуренції і монополії. При цьому співвідношення конкуренції і монополії стає стихійним - воно різне для різних країн, макроекономік і історичних епох; при цьому кризи, інфляція змінюються на періоди стабільного розвитку макроекономіки. Цієї епохі притаманна парадигма монополістичної конкурениї̈, парадигма стихійного, неконтрольованого співвідношення конкуренції і монополії, й як наслідок - встановлення неконтрольованої, стихійної рівноважної ціни.

Аналіз різних аспектів проблеми пошуку співвідношення конкуренції монополії, а також практика боротьби з монополізмом як зговором, практика використання антимонопольного законодавства у «розвинутих» країнах світу й особливо у США привів авторів до висновку про необхідність встановлення саме 
контрольованого, керованого характеру співвідношення конкуренції і монополії з боку усіх суб'єктів макроекономіки. Це зовсім не означає повну заборону всіх монополій. На думку авторів найбільш правильною глобальною стратегією зобов'язана бути парадигма оптимального співвідношення конкуренції і монополії, тобто, створенню такої рівності сукупного попиту і сукупної пропозиції, яка забезпечить мінімальну рівноважну ціну. Й це буде основою третьої, майбутньої парадигми макроекономіки Постіндустріальної епохи.

Висновки. Встановлення, визначення всіх чотирьох елементів змісту макроекономіки (основної теорії; основного закону; методики апробації основного закону - методики «ЧАС»; парадигм) дозволив вперше завершити формування науки макроекономіки. При цьому були надані такі визначення кожного з чотирьох ії елементів:

- $\quad$ Основна теорія макроекономіки, головним елементом змісту якої є основний закон макроекономіки, як результат узагальнення законів приватних теорій макроекономіки.

- $\quad$ Основний закон макроекономіки - це рівність сукупного попиту і сукупної пропозиції, яка відображає саму сутність макроекономіки - створення рівноважної ціни.

- Методика апробаиії основного закону - це вже відома методика «Час» як скорочений вираз методики історично-логічного Гегеля.

- $\quad$ Три парадигми макроекономіки (глобальні стратегії): вільної конкуренції; стихійного (неконтрольованого) співвідношення конкуренції і монополії; оптимального (контрольованого) співвідношення конкуренції і монополії.

Сформована наука макроекономіки буде найефективнішим засобом вирішення проблем практики макроекономіки та мікроекономіки, а також матиме позитивний вплив на розвиток педагогіки вищої освіти, досягнення іiі дійсно наукового рівня.

\section{Перелік посилань}

1. Бабайлов В. К. Методологія наукових досліджень : навч. посібник. Х. : ФОП Бровін О.В., 2019. 150 с.

2. Бабайлов В. К. Научность: установление критерия. Новий колегіум. 2017. № 4. С.67-70.

3. Бартенев С. А. Экономические теории и школы (история и современность): курс лекций. М. : БЕК, 1996. 352 с.

4.Основоположник вчення фізіократів Франсуа Кене. Реферат. Освіта.иа : веб-сайт. URL: https://cutt.ly/SnqQdol (дата звернення: 20.04.2021).

5. Класична політична економія в Англії: виникнення та становлення. Реферат. Освіта.иа: веб-сайт. URL: https://cutt.ly/enqQEcW (дата звернення: 20.04.2021).

6. Альфред Маршалл - творець економікс. Букліб: веб-сайт. URL: https://buklib.net/books/25495 (дата звернення: 20.04.2021).

7. Концепция социального рыночного хозяйства: формирование, развитие, современный подход. IQ.HSE.RU: веб-сайт. 
URL: https://clck.ru/UhoRH (дата обращения: 20.04.2021).
8. Монкретьен,
Антуан
де.
Википедия:
веб-сайт.

URL: https://cutt.ly/tbUcU3W (дата обращения: 20.04.2021).

9. К критике политической экономии. Википедия: веб-сайт. URL: https://cutt.ly/qbUcKDi (дата обращения: 20.04.2021).

10. Пэтти, Уильям. Википедия: веб-сайт. URL: https://cutt.ly/ObUcBP2 (дата обращения: 20.04.2021).

\section{References}

1. Babaylov, V. K. (2019), Methodology of scientific research [Metodolohiia naukovykh doslidzhen], training manual, OOP Brovin O. V., Kharkiv, 150 p.

2. Babaylov, V. K. (2017), Scientificness: establishing a criterion [Nauchnost': ustanovlenie kriteriya], New college, № 4, P.67-70.

3. Bartenev, S. A. (1996), Economic theories and schools (history and modernity) [Ekonomicheskie teorii i shkoly (istoriya i sovremennost')], a course of lectures, BEK, Moscow, $352 \mathrm{p}$.

4. The founder of the teachings of the Physiocrats Francois Quesnay. Abstract [Osnovopolozhnyk vchennia fiziokrativ Fransua Kene. Referat], available at : https://cutt.ly/SnqQdol (last accessed 20.04.2021).

5. Classical political economy in England: the emergence and formation. Abstract [Klasychna politychna ekonomiia $\mathrm{v}$ Anhlii: vynyknennia ta stanovlennia. Referat], available at : https://cutt.ly/enqQEcW (last accessed 20.04.2021).

6. Alfred Marshall is the creator of economics [Alfred Marshall - tvorets ekonomiks], available at : https://buklib.net/books/25495/ (дата звернення: 20.04.2021).

7. The concept of a social market economy: formation, development, modern approach [Kontseptsiya sotsial'nogo rynochnogo khozyaystva: formirovanie, razvitie, sovremennyy podkhod], available at : https://clck.ru/UhoRH (last accessed 20.04.2021).

8. Montchretien, Antoine de [Monkret'en, Antuan de], available at : https://cutt.ly/tbUcU3W (last accessed 20.04.2021).

9. To the criticism of political economy [K kritike politicheskoy ekonomii], available at : https://cutt.ly/qbUcKDi (last accessed 20.04.2021).

10. Patty, William [Petti, Uil'yam], available at : https://cutt.ly/ObUcBP2 (last accessed 20.04.2021). 


\section{РЕФЕРАТИ РЕФЕРАТЫ ABSTRACTS}

\section{УДК 330.101.54; JEL Classification: E00, E03, E3}

\section{Бабайлов В. К., ПриходЬко Д. О. ЗАВЕРШЕННЯ ФОРМУВАННЯ НАУКИ МАКРОЕКОНОМІКИ}

Як доведено сучасними фундаментальними дослідженнями у будь-якій науці зобов'язано бути чотири елементи змісту: об'єкт (межи науки); предмет (проблемна частина об'єкту); методика апробації, як методика вирішення проблеми предмету; парадигма (результат апробації основного закону). Відсутність хоча б одного з таких елементів означає відсутність усієї науки. Метою даного дослідження є завершення формування науки макроекономіки. Задачi: визначити чотири елементи змісту науки макроекономіки (основну теорію, основний закон, методики апробації основного закону, парадигми), сформулювати основні результати дослідження. Методики дослідження: порівняння, системного та комплексного підходу, абстрактно-логічного аналізу, узагальнення та абстрагування, логічна генерація висновків. Результати. Визначені всі чотири елементи змісту науки макроекономіки: основна теорія макроекономіки, головним елементом змісту якої є основний закон, як результат узагальнення законів приватних теорій макроекономіки; основний закон макроекономіки - це рівність сукупного попиту і сукупної пропозиції, яка відображає саму сутність макроекономіки - створення рівноважної ціни; основна методика апробаиії основного закону - методика «Час» як скорочений вираз методики історичного-логічного Гегеля; три парадигми макроекономіки (глобальні стратегії) відповідно: вільної конкуренції; стихійного (неконтрольованого) співвідношення конкуренції $\mathrm{i}$ монополії; оптимального (контрольованого) співвідношення конкуренції i монополії. Це означає завершення формування науки макроекономіки. Наукова новизна: вперше завершено формування науки макроекономіки. Практична значущість: сформована наука макроекономіки буде найефективнішим засобом вирішення проблем практики макроекономіки та мікроекономіки, а також матиме позитивний вплив на розвиток педагогіки вищої освіти.

Ключові слова: макроекономіка; наука; об’єкт; предмет; апробація; основна теорія, основний закон; методика «Час»; парадигма.

\section{УДК 330.101.54; JEL Classification: E00, E03, E3}

Бабайлов В.К., ПриходЬКо Д.А. ЗАВЕРШЕНИЕ ФОРМИРОВАНИЯ НАУКИ МАКРОЭКОНОМИКИ

Как доказано современными фундаментальными исследованиями в любой науке обязано быть четыре элемента содержания: объект (границы науки); предмет (проблемная часть объекта) методика апробации, как методика решения проблемы предмета; парадигма (результат апробации основного закона). Отсутствие хотя бы одного из таких элементов означает отсутствие всей науки. Целью данного исследования является завершение формирования науки макроэкономики. Задачи: определить четыре элемента содержания науки 
макроэкономики (основную теорию, основной закон, методики апробации основного закона, парадигмы), сформулировать основные результаты исследования. Методики исследования: сравнения, системного и комплексного подхода, абстрактно-логического анализа, обобщения и абстрагирования, логическая генерация выводов. Результаты. Определены все четыре элемента содержания науки макроэкономики: основная теория макроэкономики, главным элементом содержания которой есть основной закон, как результат обобщения законов частных теорий макроэкономики; основной закон макроэкономики - это равенство совокупного спроса и совокупного предложения, которое отражает саму сущность макроэкономики - создание равновесной цены; основная методика апробации основного закона - методика «Время» как сокращенное выражение методики исторического-логического Гегеля; три парадигмы макроэкономики (глобальные стратегии) соответственно: свободной конкуренции; стихийного (неконтролируемого) соотношения конкуренции и монополии; оптимального (контролируемого) соотношения конкуренции и монополии. Это означает завершение формирования науки макроэкономики. Научная новизна: впервые завершено формирование науки макроэкономики. Практическая значимость: сформированная наука макроэкономики будет эффективным средством решения проблем практики макроэкономики и микроэкономики, а также окажет положительное влияние на развитие педагогики высшего образования.

Ключевые слова: макроэкономика; наук; объект; предмет; апробация; основная теория; основной закон; методика «Время»; парадигма.

\section{UDC 330.101.54; JEL Classification: E00, E03, E3 \\ Babailov V.K. , Prykhodko D.O. COMPLETION OF THE FORMATION OF THE SCIENCE OF MACROECONOMICS}

As proved by modern basic research, any science must have four elements of content: object (boundaries of science); subject (problem part of the object); method of approbation, as a method of solving the problem of the subject; paradigm (the result of approbation of the basic law). The absence of at least one of these elements means the absence of all science. The purpose of this study is to complete the formation of the science of macroeconomics. Objectives: to determine the four elements of the content of the science of macroeconomics (basic theory, basic law, methods of approbation of the basic law, paradigms), to formulate the main results of the study. Research methods: comparison, systematic and complex approach, abstract-logical analysis, generalization and abstraction, logical generation of conclusions. Results. All four elements of the content of the science of macroeconomics are defined: the basic theory of macroeconomics, the main element of the content of which is the basic law, as a result of generalization of the laws of private theories of macroeconomics; the basic law of macroeconomics is the equality of aggregate demand and aggregate supply, which reflects the very essence of macroeconomics - the creation of an equilibrium price; the main method of approbation of the basic law - the method of «Time» as an abbreviated expression of 
the method of historical and logical Hegel; three paradigms of macroeconomics (global strategies), respectively: free competition; spontaneous (uncontrolled) ratio of competition and monopoly; optimal (controlled) ratio of competition and monopoly. This means the completion of the formation of the science of macroeconomics. Scientific novelty: the formation of the science of macroeconomics has been completed for the first time. Practical significance: the established science of macroeconomics will be the most effective means of solving problems of practice macroeconomics and microeconomics, and will also have a positive impact on the development of higher education pedagogy.

Key words: macroeconomics; science; object; subject; approbation; basic theory; basic law; method «Time»; paradigm.

\section{Відомості про авторів / Сведения об авторах / About the Authors}

Бабайлов Василь Кузьмич - кандидат економічних наук, Харківський національний автомобільно-дорожній університет, доцент кафедри економіки i підприємництва, м. Харків, Україна; e-mail: super_super-kod @ukr.net.

Бабайлов Василий Кузьмич - кандидат экономических наук, Харьковский национальный автомобильно-дорожный университет, доцент кафедры экономики и предпринимательства, г. Харьков, Украина.

Babailov Vasil - PhD, Kharkiv National Automobile and Highway University, Associate professor of the Department of Economics and Entrepreneurship, Kharkiv, Ukraine.

Приходько Дар'я Олександрівна - кандидат економічних наук, доцент, Харківський національний автомобільно-дорожній університет, доцент кафедри економіки і підприємництва, м. Харків, Україна; e-mail: zajada@gmail.com; ORCID: https://orcid.org/0000-0003-3925-4828. Моб. 066-97-44-135.

Приходько Дарья Александровна - кандидат экономических наук, доцент, Харьковский национальный автомобильно-дорожный университет, доцент кафедры экономики и предпринимательства, г. Харьков, Украина.

Prykhodko Daria - PhD in Economics, Associate Professor, Kharkiv National Automobile and Highway University, Associate Professor of the Department of Economics and Entrepreneurship, Kharkiv, Ukraine. 